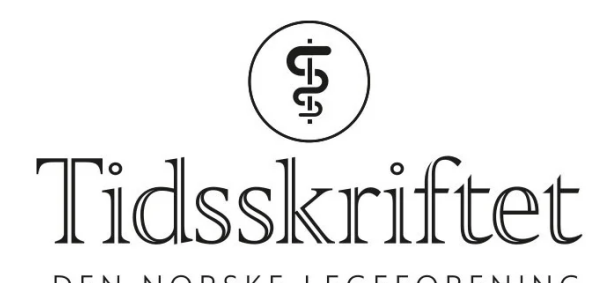

DEN NORSKE LEGEFORENING

\title{
Er nynorsk en fare for folkehelsen?
}

TIDLIGERE I TIDSSKRIFTET

ÅSLAUG FLO

Email: aaslaug.flo@legeforeningen.no

Tidsskriftet

I Tidsskriftet nr. 10/1932 kommer redaksjonen med et nokså surt bidrag til språkstriden fordi det i en utlysning av fylkeslegeembetet i Hordaland var stilt krav om nynorskkunnskaper (Tidsskr Nor Lægeforen 1932; 52: 667-8). Folkehelsearbeidet vil bli skadelidende hvis vedkommende «kan være så stor idiot han vil» bare han bruker nynorsk, hevdes det. Dagens redaksjon er atskillig vennligere innstilt til Ivar Aasens arbeid.

Oslo, 6. mai 1932.

\section{Et tidehverv.}

De som leser «Tidsskriftet»s byråmeddelelser, la sikkert merke til de tilleggslysninger, som i siste nummer var inntatt angående fylkeslægeembetet i Hordaland og distriktslægestillingene i Herøy S., Vikna og Stord. Også ved de offentlige lægestillinger vil det altså herefter ikke bare bli spørsmål om kvalifikasjon hos søkerne, men også om sprogkunnskaper. Det heter i kunngjørelsen at man skal oplyse om man «kann nynorsk». Hvor meget dette uttrykk innebærer har vi ikke kunnet bringe på det rene.

I og for sig har vi naturligvis intet imot at de offentlige læger har kunnskaper i nynorsk, selv om det er lite eller ingen bruk for det. De som lægene står i offisiell korrespondanse med, forstår alle sammen riksmål ; men kravet om kunnskaper i nynorsk innebærer den fare, at det blir disse kunnskaper og ikke de som er av betydning, som blir avgjørende ved besettelse av stillingene. De som muligens vil si at vår frykt her er ugrunnet, at vi overdriver, henvises til en artikkel i «Dagbladet» av en Torvald Engjadal : «Det munar». Det heter her blandt annet : «No er endeleg turen komen til lækjarane og no lyt dei syne vyrdnad for folkeviljen um dei vil ha embete i bygder der nynorsken rår grunden.» «Og det 
at no fær me ein fylkeslækjar i Hordaland som både vil og kan bruka det nynorske målet.» Det er vel ikke tvil om at for denne herre er det eneste saliggjørende at fylkeslægen bruker nynorsk, forøvrig kan han være så stor idiot han vil.

Vi har tidligere kritisert ansettelse av fylkeslæger og fremholdt disse stillingers overordentlig store betydning for hele det hygieniske arbeide. Vi har beklaget hvorledes fremdeles hos oss det profylaktiske arbeide fører en kummerlig tilværelse og hvor smått det fremdeles går med å få gjennemført en bedre hygiene på landsbygden. Vi er redd det herefter vil gå ennu langsommere, for efter vårt kjennskap til forholdene har vi neppe nogen læge for tiden som er medisinsk kompetent til å beklæ Hordaland fylkeslægestilling og som samtidig behersker nynorsk.

Red.

I tilslutning til ovenstående kan vi ikke motstå fristelsen til å gjengi nedenstående fra «Nationen» for 28. april i år :

Av Nationen om 100 år.

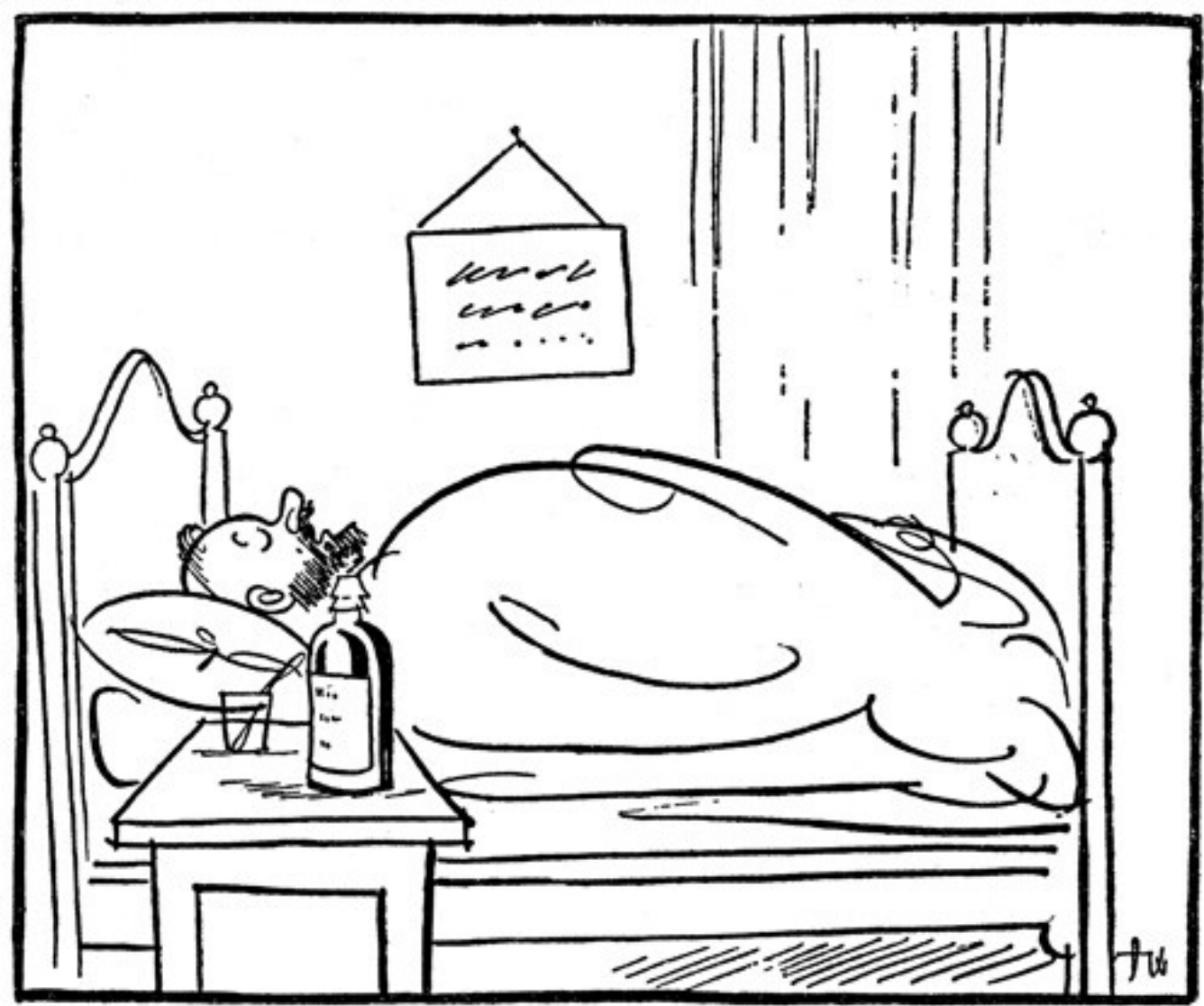

Torstak, 28. april 2032. Ter ser vi følken.Ein mann på Stort tøytte ikår ; avti tistriktslekjaren ikkje kunte skriva resept på styrkjetrykk på nynorsk.

Publisert: 11. juni 2013. Tidsskr Nor Legeforen. DOI:10.4045/tidsskr.13.0574

(C) Tidsskrift for Den norske legeforening 2023. Lastet ned fra tidsskriftet.no 26. april 2023. 